Ssciendo Studia Anglica Posnaniensia 56 (2021): 209-233

doi: 10.2478/stap-2021-0023

\title{
JOHN LYDGATE'S GUY OF WARWICK AND FIFTEENTH-CENTURY EMOTIONS
}

\author{
ANNA CZARNOWUS ${ }^{1}$
}

\begin{abstract}
The article argues that John Lydgate's Guy of Warwick is an innovative version of the Guy of Warwick legend as it emphasizes the feelings of its characters. Furthermore, it also openly intends to evoke emotions in its audience. The poem requires to be read in light of the newly emerged field of the history of medieval emotions since the social context of Lydgate's Guy is more visible from this perspective. The poem offers an admixture of religious and secular feelings. As a result, the final scenes of bidding farewell to Guy by Felice and by the community have to be seen as related both to Guy as a hero and as a saint.
\end{abstract}

Keywords: History of emotions; John Lydgate; Guy of Warwick; religious and secular feelings; holiness.

In her discussion of The Temple of Glass, Wilson inquires as to whether John Lydgate is a precursor of Renaissance values in the poem (Wilson 1975: 25). We may ask a similar question about Guy of Warwick; not in terms of discussion of the courtly love conventions, as Wilson does, but in reference to the sustained expression of feelings in Lydgate's narrative. His poem is set 900 years after the birth of Christ, so it demonstrates a fifteenth-century vision of the Old English past. Its ideas of emotionality are related to the expectations of its fifteenthcentury audience. Lydgate's poem includes fifteenth-century piety and the moralizing that entered secular texts at the time. This poem confirms the identification of Lydgate as a pious poet, willing to introduce religious topics into narratives which were secular in previous versions. ${ }^{2}$ The emotions that he

1 Department of Literary Studies, University of Silesia, ul. Grota Roweckiego 5, 41-200 Sosnowiec, Poland, e-mail: anna.czarnowus@us.edu.pl

2 Yet another reading of the poem could be hagiographic even though it is a poem on the concepts of masculinity at the same time; the topic of holiness and masculinity is introduced, among others, by Cullum (2004). 
elaborates on in Guy - anger, sadness and joy (and weeping as a demonstration of the two), religious devotion, astonishment, and grief, both individual and communal - give more validity to his version of the legend and show how vehement emotions from romance, a genre popular with the middle class, enter other literary forms. At the end of Guy, Lydgate introduces feelings as not just religious but communal, and not necessarily related to religion. The investigation of emotions that is to be conducted here could enrich the developing field of the history of emotions since it aims to analyze the expression of emotions in the poem and the social context for such expression. Such an analysis will both build on previous research done within the history of emotions and take it further.

Lydgate's Guy of Warwick belongs to a group of texts whose hero is no longer fashionable, as Richmond (1996: 3) notes. Lydgate, who lived ca. 1370-1449, was the favourite poet of the court of King Henry VI even though, formally, he remained a monk at Bury St. Edmunds. He authored romances, such as The Troy Book and The Siege of Thebes, but also minor poems and translations. His Guy of Warwick, probably written in the mid-1440s, is a translation from the Latin chronicle of Gerard of Cornwall (Gerardus Cornubiensis). The poem was commissioned by Margaret Beauchamp, Countess of Shrewsbury and daughter of Richard de Beauchamp, Earl of Warwick (1382-1439). The narrative was intended to please her father, for whom Guy was a legendary ancestor. Warwick was the most important supporter of the Lancastrians; Lydgate was attached to them as well. The scribe John Shirley, from whose workshop numerous copies of Lydgate's poem came, belonged to Warwick's retinue. ${ }^{3}$ Importantly, Shirley's clientele included both aristocracy and middle class: mercers, lawyers, and burghers in general (Richmond 1996: 124). The popularity of the poem beyond the aristocracy is testified to by "the evidence of the manuscripts [which] indicates that those in which Guy appears reflect commercial patterns of book circulation" (Edwards 2007: 90). Edwards notes "the larger commercial factors that shaped the production of manuscripts of Lydgate's shorter poems" (Edwards 2007: 91), including Guy. The commercial production and distribution is evidence that the poem was popular with a larger public. It was not a merely chivalric text, but a poem about a holy figure generally venerated in the fifteenth century, including among the middle class, who created an audience for diverse versions of the Guy legend.

It may be assumed that Lydgate's poem catered to the interests of the middle class as well as those of the aristocracy, whose representatives commissioned the poem. On the one hand, it appealed to fifteenth-century piety, which was characterized by moralizing not only in religious literature but in various secular texts. ${ }^{4}$ Stress was laid on penitence in this period as well, which led to literary

For more on John Shirley's work, see Connolly (1998).

$4 \quad$ Richard Newhauser writes about the "secularization of moral teaching during the High and Later Middle Ages" (Newhauser 2007: 2). 
characters frequently expressing their humility in front of God. The demonstration of affect became the norm in literary texts and tears were shed profusely in various contexts, including religious ones. Characteristically, Lydgate's Life of our Lady demonstrates this late medieval affective piety. The poem combines personal devotion expressed with enormous feeling with the imagery and even specific phrases characteristic of Marian devotion. Life of our Lady stems from the narrator's "thoughtful heart" (Garnett 1903: 186) and situates the figure of the Virgin Mary against the background of classical allusion. In Guy of Warwick, similar tendencies are noticeable. Furthermore, Lydgate writes about emotions in a manner which makes the narrative more lively than the account in the chronicle on which his poem was based, as Schirmer argues:

In general he follows the chronicle accurately, making omissions only where the
material is of purely local interest, and expanding it by verbose digressions and
reiterations, mythological and scriptural allusions, including images from nature
and human emotions [emphasis mine].

(Schirmer 1961: 93)

Edwards identifies the poem as situated on the boundary between a saint's life and a romance (Edwards 2007: 89). There is space for expressing human emotions in both of these genres, which this article will attempt to demonstrate. The numerous references to feelings in the poem may have resulted from the expectations of the new type of audience, the middle class, who were already used to reading about emotions in popular romance. This could explain the popularity of Lydgate's poem, and it allows us to see the poet, who these days is very much overshadowed by Chaucer, as someone who developed the discussion of emotions in literary texts.

Lydgate's version of the Guy of Warwick legend is simultaneously more religious than the previous versions of the legend, such as the Stanzaic Guy of Warwick from the turn of the fourteenth century, and is intended for a different audience. The combination of the religious and the secular is oriented towards a large reading public, which included the middle class. In Lydgate's Guy of Warwick, the stress laid on the religious part of the narrative seems to ennoble the whole story, and the emotions expressed there may be given more validity because they appear in a narrative about a holy person. Importantly, the religious narrative has to be classified as a popular text due to its devotional topic (Radulescu \& Rushton 2009a: 6), so Guy belongs to popular literature, both as a hagiographic narrative and as a romance.

The choice of the central character is not innovative. The main texts about the legendary hero are the Anglo-Norman poem Gui de Warewic (Richmond 1996: 7), Speculum Guy of Warwick from the early fourteenth century, called a verse homily; the metrical Auchinleck Guy of Warwick in couplets; and the Stanzaic Guy of Warwick, which begins where the Auchinleck version ended. 
However, the Stanzaic Guy is a romance that was composed independently from other versions, not as their continuation (Wiggins 2004). All of them "embodied contemporary attitudes," as Richmond (1996: 127) claims. ${ }^{5}$ It is therefore not surprising that Lydgate's version voices the fifteenth-century perspective on emotionality and seems to reflect both the piety of the period and the outpouring of emotional expressiveness that characterized the time. Jane Chance reminds us that Lydgate's inspirations were twofold. On the one hand, he was familiar with classical Latinate and early medieval texts; on the other, he knew "didactic and moralizing" vernacular tales and incorporated them into his work (Chance 1999b). Both types of sources are present in his Guy, since he frequently refers to such deities as Phoebus and Mars, yet ends his poem on a highly moralistic tone. Importantly, he complements his source materials with references to feeling, which adds a new dimension to a text otherwise suffused with classical allusion and fifteenth-century didacticism.

Lydgate's Guy of Warwick, perhaps artistically not as accomplished as his Troy Book or The Temple of Glass, on the one hand, reflects the conservative orthodoxy of its fifteenth-century audience, which consisted not only of the aristocracy but of the middle class as well. On the other hand, it is focused on feeling. Not all these feelings are entirely new to a narrative about the legendary English hero. The Stanzaic Guy of Warwick includes passages similar to the ones in Lydgate's Guy, but the overall effect in the stanzaic poem is different. The Stanzaic Guy was composed around 1300 and included mostly references to Guy's adventures in the East and West; for example, confrontations with the Egyptian giant Amorant and Guy's encounter with his old friend Tirri in Germany. ${ }^{6}$ The translator of the AngloNorman Gui de Warewic (composed ca. 1220) limited himself to one-third of the original material in his Stanzaic Guy of Warwick, focusing on Guy's later adventures. Lydgate focuses on the hero's later life even further, since he emphasizes the religious dimension of the narrative and thus places the emotions from the narrative in the framework of what looks like fifteenth-century piety. If the redactor of the Stanzaic Guy of Warwick emphasized the legend's hagiographic context, Lydgate did this even more visibly. Lydgate's version is even shorter, as it numbers only 592 lines, in contrast to the 3500 lines of its predecessor, and concentrates mostly upon Guy's life as a hermit.

Lydgate omits references to the earlier adventures of Guy and starts by confronting his audience directly with the Danish invasion of England, which is related to the difficult feelings of the characters and probably of the audience as well. Lydgate does not distinguish between secular emotions and religious ones, with the latter exemplified in the text by what happens to Ethelstan during his

For more on the many versions of the legend, see Mehl (1968: 211-219), Ramsey (1983: 45 68), Crane (1986: 62-67), and Hopkins (1990: 45-68).

6 For a synopsis of the Guy of Warwick narrative, see Wiggins (2007: 201-202). 
prayer to God for a champion. ${ }^{7}$ This combination of secular and religious feelings easily matches the construction of Guy's identity, since he is both a knight and a hermit; at times, it is difficult to tell whether the feelings he provokes are directed towards a layperson or a holy man. The emotions of his wife Felice towards him seem complex, and so are the feelings his death inspires in the community.

In the past, the history of emotions was largely a field analyzed in the context of the eighteenth-century and Romantic culture; turning to pre-modern times is a relatively new gesture within the field. Going further and further back in analyzing past emotions has led to an emerging interest in medieval emotionality, an interest that has since been labelled the "affective turn" (Trigg 2014: 3). In the humanities, discussion of emotionology as the history of emotions probably started with Stearns \& Stearns (1985: 813-836), who defined the field in the essay Emotionology: Clarifying the History of Emotions and Emotional Standards. This was followed by, among other works, William Reddy's theoretical study Navigation of Feeling: A Framework for the History of Emotions (2001) and Martha Nussbaum's Upheavals of Thought: The Intelligence of Emotions (2003). Then, such periodspecific discussions of the subject as, for example, Emotional Lexicons: Continuity and Change in the Vocabulary of Feeling 1700-2000 (Frevert et al. 2014), and Emotions and Social Change: Historical and Social Perspectives (Lemmings \& Brooks 2014) were published. The field was broadened in these studies and similar ones, and concurrently the study of medieval European emotions started. Research devoted to early and late medieval Europe was conducted by Barbara H. Rosenwein $(1998,2007)$. Damien Boquet \& Piroska Nagy have also contributed much to this sphere of investigation $(2010,2018)$. More recent explorations of medieval Europe from this perspective are, for instance, the essay collections A History of Emotions, 1200-1800 (Liliequist 2012); Understanding Emotions in Early Europe (Champion \& Lynch 2015); Emotion in Old Norse Literature: Translations, Voices, Contexts (Rikhardsdottir 2017); Tears, Sighs and Laughter: Expression of Emotions in the Middle Ages (Förnegård et al. 2017); Affective and Emotional Economies in Medieval and Early Modern Europe (Marculescu \& Métivier 2017b); and Performing Emotions in Early Europe (Maddern, McEwan \& Scott 2018). None of the above, however, deals exclusively with medieval English literature and culture.

Medieval English literature has recently been analyzed from the perspective of the history of emotions by both scholars of Old and Middle English. As far as Old English is concerned, there are, for example, Anglo-Saxon Emotions: Reading the Heart in Old English Language, Literature and Culture (Jorgensen, McCormack \& Wilcox 2015) and linguistic studies of the specific vocabulary used to express emotions (Izdebska 2015). In the field of Middle English, feeling in romance is discussed in Emotions in Medieval Arthurian Literature: Body,

7 As for purely religious emotions McNamer (2010), for example, discusses Christian compassion as a religious emotion. 
Mind, Voice (Brandsma, Larrington \& Saounders 2015), Pre-modern Emotions, a special issue of Exemplaria (Trigg 2014), and Facing up to the History of Emotions, a special issue of postmedieval (8/2017, edited by Stephanie Downes $\&$ Stephanie Trigg). All this activity shows that the field of the history of emotions has recently been expanding in the study of medieval English literature, but many topics still remain to be addressed. Concerning fifteenth-century texts, there is a need to examine whether the popularity of romance among middle-class readers (Pearsall 1988: 11-12) led to any changes in writing about emotions and whether late medieval piety influenced the manner of writing about feeling in these texts. ${ }^{8}$ After all, some of these texts, like Lydgate's Guy of Warwick, are identifiable both as romances and as saints' vitae.

The need to discuss feeling, especially as something that needs to be expressed, seems to have been more natural in religious prose and poetry, as in the cases of, for instance, English Ancrene Riwle, Ladder of Perfection, and such Franciscan texts as Bonaventure's Lignum Vitae indicate. A poem where the characters openly vented their sorrow and grief through weeping must have been a novelty, to a certain extent. The discussion of how feelings are expressed could take place due to the partly religious subject matter of this poem about a miles Christi turned hermit. In the text, we witness a gradual bridging of what Brandsma \& Larrington (2015: 2) called "a gap between modern and medieval emotional regimes and communities". Lydgate's poem may establish a temporary emotional community of readers who are interested both in its religious content and in the emotions voiced within it. What strikes us in Lydgate's poem is the range of feelings expressed, along with the fact that they are named, rather than being left to inference.

The fifteenth century was a period when this gap between medieval and modern emotions started to be filled with a more modern approach to affect, one that allowed feeling to be discussed at length in secular texts. Le Goff (1989) correctly saw the late Middle Ages as a time of emotional release, since this is when narratives started to be replete with feeling. While such narratives as Chaucer's Troilus and Criseyde focus on emotions, as Larrington demonstrates in her text Embodiment and Action (forthc.), other romances were more limited in the range of feelings discussed, their specific names, and the somatic manifestations of emotions. In Troilus, Chaucer seems to have been one of the precursors of elaborating on emotions in the secular context, along with the anonymous author of Floris and Blancheflour. ${ }^{9}$ In Lydgate's Guy, one finds a range of feeling from the start of the narrative, which makes it quite different from such versions of the narrative as the Stanzaic Guy of Warwick.

8 In this study, I will consistently refer to medieval "emotions" and "feelings" in order to avoid the eighteenth-century term "sentiments"; McNamer (2007: 247) advises scholars to use the authentic Middle English term "feeling" in the context of medieval literature.

9 I thank Professor Larrington for letting me see her draft chapter on this topic from the monograph in progress. 
In the fifteenth century, feeling became more frequent in literary texts. In Lydgate's poem, the specific emotions which find an outlet are anger, distress, feelings resulting from religious devotion, astonishment, and then sadness and grief. This study does not suggest that these were real fifteenth-century emotions, but rather those which the audience expected to find in texts and probably would enjoy listening to or reading it. Wilson situates this poem, along with Lydgate's work in general, in the context of social change in the fifteenth century:

The delicate balance between reader and poet was upset; the patronage of literature
began to fall into the hands of the new moneyed man, whose literary taste was
conservative and dominated by the preceding tradition: the result of these economic
and social changes is also reflected in the mood of somber orthodoxy and
seriousness which persisted in the fifteenth century.

(Wilson 1975: 27)

The "somber orthodoxy" is visible in Lydgate's Guy of Warwick, since the central hero is presented as yet another knight who, in the end, aspires to holiness and achieves it. Such a narrative was not new in and of itself. Already chansons de geste had recorded "the development of the epic hero from the historical warriorturned-monk" (Muir 1975: xiv). Nonetheless, for the narrator to make the audience feel enraged and upset and then provide them with references to difficult feelings - this is a considerable novelty in Lydgate's poem. The "new moneyed man" Wilson (1975: 27) writes about is exposed to this expression of feeling, as much as aristocrats are interested in the legend of Guy as a genealogical and cultural heritage interest.

Barbara H. Rosenwein, one of the most important critics within the field of the history of emotions, notes that in her opinion, this discipline hinges on change as something natural for expressing emotions over the centuries. She writes that we cannot expect the expression of feeling to be the same, regardless of the cultural period under review (Rosenwein 2012). Instead, she argues that expression of emotions understood here as somatic expression, lexical items, and eliciting contexts, should be studied on its own, without generalizations which elide distinct periods (Rosenwein 2012). Marculescu and Morand-Métivier note that Rosenwein's model of the history of emotions does not adequately account for change as something focal for expression of feeling, since "emotional norms ... are imparted by different discriminate ruptures, negotiations and practices" (Marculescu \& Métivier 2017a: 2-3). ${ }^{10}$ Change is thus an even more focal point of the history of emotions than Rosenwein claims. In the case of Lydgate's Guy of Warwick, we have the context of the audience responding to a text which contains both a religious plot and a set of emotions not purely of a religious

10 There are even scholars who argue that actual emotions themselves change and not just their expression; see, for example, Nagy (2017: 14). 
nature. Emotions can be expected to be performed and negotiated by the audience, rather than just felt and expressed.

As for emotions in and around Lydgate's Guy, the author attempts at first to arouse specific feelings in the readers. Brandsma, Larrington \& Saunders comment on evoking readers' emotions in the following manner: "Literary texts, in particular romance texts, not only represent literary characters as experiencing emotion and reacting emotionally to the behaviour of others within the text but they also, intentionally, evoked and played upon emotion in the audiences who heard and saw them performed or read" (Brandsma \& Larrington 2015: 7). Lydgate begins his poem with a vision of England in the times of King Ethelstan and the destruction wrought there by Danes:

Duryng also the persecucyoun

Of them of Denmark, wich with myhty hond

Rod, brente, and slouh, made noon excepcioun,

By cruel force, thorugh out al this lond;

Spared nouther hi nor louh degre,

Chirchis, collegis, and euery greet cyte

In ther ffurie, by ffals oppressioun,

On-to the boundys of Wynchestre toun,

With suerd \& feer they madyn al wast \& wylde;

And in their mortall persecucyoun

Spared nat women greet with chylde;

...

[Also during the persecution

By those of Denmark, who with mighty hand

Raided, burnt, and slain, making no exception,

By cruel force, throughout all this land;

They spared neither people of high nor of low degree,

Churches, collegiates, and every great city

In their fury, by deceitful oppression,

Onto the borders of the town of Winchester,

With sword and fire they made all waste and wild;

And in their mortal persecution

Did not spare women great with child;

...]

$(G W 5-16)^{11}$

The Danes' "ffurie" would presumably elicit the audience's rage at those who had plundered their England, who "rod, brente, and slouh" all, including those who were not warriors. The vision of "women greet with chylde" who were murdered

11 The line numbers preceded by the abbreviation $G W$ come from McCracken's edition (1997 [1911]); all the subsequent translation into modern English is mine. 
is deliberately gruesome. The readers' supposed outrage is a natural reaction to the fury of the invaders expressed in the narrative. ${ }^{12}$ Lydgate skillfully manipulates the feelings of his audience to create a division into "us," the English from the past and possibly also from the poet's present, and "them", the barbarians.

This is how Lydgate continues the line of thinking about Englishness established by earlier ancestral or legendary romances, such as the earlier versions of the Guy legend, but also by Sir Bevis of Hampton and Richard Coeur de Lion (Radulescu 2009: 46). Also, Haveloc the Dane discussed what it meant to be English (Turville-Petre 1994: 121-134). The idea of Englishness in romance developed particularly in the thirteenth and fourteenth centuries, which reflected its centrality both in politics and in culture from the eleventh to the fourteenth century. ${ }^{13}$ Still, the debate about what Englishness meant remained unsolved (Davies 2000; Gillingham 2000). This concept was framed in opposition to Saracens (Bly-Calkin 2005) and Normans, but, according to Anderson, it never reached a fixed form before the eighteenth century (Anderson 1991). As Crofts and Rouse note, in the Auchinleck manuscript, there is "the simplicity of Guy's conception of Englishness" (Crofts \& Rouse 2009: 83). A similar simplicity is noticeable in Lydgate's Guy: the Danes' attack is characterized by fury; thus, the English are those who are supposed to react to this fury with comparable anger, but this emotion is justified here. The Danes are described as mad or extremely angry with the English: "thes Danussh pryncis ageyn wer so wood" [these Danish princes were again so mad] (GW 26). They are "wood and wylful in ther marcyal rage" [mad and willful in their martial rage] ( $G W$ 138). It is expected of the English to be equally angry with them in return. Lydgate continues the line of thinking about Englishness as that which is not Other in religious and cultural terms, but he adds a load of powerful emotions to emphasize that the Danes directed their fury against the English and the English replied with anger.

Yet another powerful emotional effect that the poem may have produced in its audience was that of fear. Such is the function of the following passage:

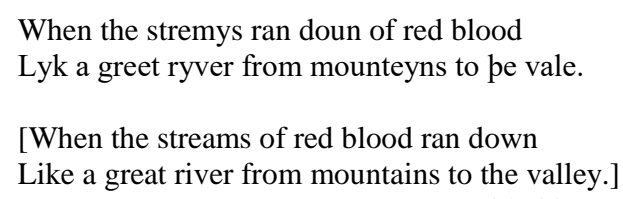

The audience is made to understand that there is a specific need for defending England against its cruel invaders. Then the focus begins to fall on King Ethelstan

12 For a discussion of anger as a powerful medieval emotion, see the studies by the contributors in Rosenwein (1998).

13 For a discussion of the Englishness of Haveloc the Dane, see Field (2009: 25). 
himself as the one who should react to the events effectively. If the inhabitants of early medieval England are angry at the violence that surrounds them, he should be enraged as well. When the audience are filled with dread at "the stremys ... of red blood", Ethelstan must be terrified, too. As a result, Ethelstan is introduced to us in the character of a knight, but his social status does not protect him from experiencing very strong feelings:

Kyng Ethelstan was a ffull noble knyght, Though for a tyme eclypsed was his lyght; Of his noblesse and royall mageste,

The hand of god stood alway in his myght

To chaunge his trouble in-to prosperyte.

[King Ethelstan was a very noble knight, Though the light was eclipsed for some time Of his nobility and royal majesty,

The hand of God always remained in his power

To change his trouble into prosperity.]

$(G W 76-80)$

This is natural: as a ruler, Ethelstan needs to show feelings that play a communal role, and here, the feeling is probably sadness, since this is how we could read the passage: "eclypsed was his lyght". He normally glows with the radiance of the ruler of a prosperous country, but this light may be eclipsed by sorrow, or even anger, at the enemies for their attack. The anger may be a force that unites the English against the atrocious Danes. Chansons de geste had already made use of anger in this manner, as White writes about Le Chanson de Roland, where "special prominence" is given to anger and grief, and also about other chansons de geste (White 1998: 132).

Knighthood is compared here to a light which is supposed to shine and enlighten those who do not belong to the upper class. Ethelstan must be depressed over the misfortunes that have fallen upon his country. God helps him in reaching some balance and thinking about the solution to the serious crisis. When the Danes demand tribute, Ethelstan abandons all his brooding and searches for a champion who will confront their giant, Colebrand:

Of ellis pleynly of partyes covenaunt

Kyng Ethelstan for hym to ffynde a knyght

With Colbrod of Denmark the Geaunt,

Day assigned, to entre with hym in ffyght,

For to darreyne atween hem to right,

Who shal reioisshe, with strong and myhty hond,

To holde a sceptre, by manhood and by myght,

And haue poscessioun in quyete of this lond.

[Of else plainly of the parties' agreement

That King Ethelstan will find a knight

With Colebrand the Giant of Denmark, 
On the assigned day to enter the figh,

So as to stay rightfully engaged in this combat between the two of them,

Who shall rejoice, with a strong and mighty hand,

To hold a scepter, with manliness and strength

And be the ruler of the peace of the land.]

(GW 121-128)

The king's turbulent emotions must be then at least partly assuaged through the action he undertakes, which shows that Lydgate understood that the role of anger was also to inspire someone to take action.

Perhaps anger is even expected from the king here, since, as Althoff remarked in the context of medieval chronicles and similar historical sources, royal anger could be a part of the "rulership practice" (Althoff 1998: 59), even though, at the same time, the king was not supposed to display this anger, but rather feel it and punish his subjects like an angry man would (Althoff 1998: 61). Ira Regis can be a powerful weapon if it is displayed in a controllable manner, and it is part of good governance. In this sense, Lydgate's Guy is similar to his Troy Book, which Witalisz (2011) interprets as a medieval mirror for princes, i.e., a book of princely advice. Both in Guy and The Troy Book, Lydgate features as "the moral interpreter of history" (Witalisz 2011: 98), who advises princes on how to behave. In the latter narrative, Hector is praised as an exemplary prince. Ira Regis may be seen as part of justice, as recommended to princes (Witalisz 2011: 124-127), since anger may be a demonstration of justice when it is intended to rectify the comportment of the subject.

Even if Ethelstan is one of several angry men in the narrative, and not the only one, his outrage is what is most visible at this point. He becomes even more upset, since he cannot find a champion able to defend him and his people:

This apoyntment so streitly was forth lad, Of ffurious haste they wolde haue no delay, Kyng Ethelstan so hard[e] was be-stad, And alle his pryncis put in gret affray;

Affore Wynchestre the proude dukis lay,

The Kyng withinne, astoned in his mende,

And weel pe more, be-cause he knew no way

In his dyffence a champioun to ffynde.

[This appointment was laid forth so straightly.

They would have no delay, out of furious haste,

King Ethelstan was hard-pressed,

And all his princes were greatly assaulted;

Before Winchester the proud dukes had their camp,

The King was within, astounded in his mind,

And even more, because he knew no way

To find a champion for his own defense.] 
The fear that Lydgate initially expected to provoke in his audience is projected onto the higher levels of the society he presents. At first, the readers were made to feel terrified at the violence directed even against women and children, including pregnant women, and now, even Ethelstan's princes are scared of violence, this time that which Colebrand will direct, possibly even against them. Fewer and fewer people in the kingdom can resist the aggression directed upon them. Ethelstan is described as "astoned", which means "astounded." The etymology of the word derives from the vulgate Latin extonere, to "be struck by thunder". The king is utterly amazed, which extends the range of feelings presented in the narrative. The onset of emotions, such as feeling astonished, makes one closer to the natural world, here represented by a tempest. Being astounded is like being affected by thunder, which shows how close one is to nature, and not only one's inner nature when one begins to feel something. This astonishment is overcome once Ethelstan manages to find a champion, whose actions will remedy the effects of the Danes' fury. Finding the knight who will defeat the giant appears to be Ethelstan's only goal at this point. Locating Guy, "Erl of Warwyk, named oon the beste knyht" (GW 182), is necessary for the survival of Ethelstan's people.

The pious tones are present in the narrative in the part which narrates what happened to Guy once he stopped being just yet another crusader:

He lyk a pilgrim endewed with all vertu

The nexte morwe chaunged hath his weede, And spedde hym forth for love of Crist Ihesu;

Forsook the world, onknowe to euery wight,

Of hih perfeccyon to leven in penaunce,

Lefft wyff and kyn, and bekam Goddis knyght,

Whom for to serve was set all his plesaunce,

Content with lytel, Crist was his suffysaunce,

In wordly pompe he lyst not to soiourne. -

[He, like a pilgrim endowed with all virtue

Changed his clothes on the next morning,

And speeded forth for the love of Jesus Christ;

Forsook the world, unknown to every living creature,

Of high perfection to live in penance,

Left his wife and kin, and became God's knight,

To whom serve was all his pleasure,

Satisfied with little, Christ was what was sufficient for him

In wordly display of wealth he did not want to remain. - ]

(GW 190-198)

Guy's piety was extreme, since he abandoned his wife Felice, here already pregnant with a child who was going to be called Raynbourne, and became a miles Cristi. At this point, Lydgate is very moralistic in the Christian manner: marital love is spiritual and all eroticism in marriage aims merely at reproduction. 
When Guy abandons his wife, he starts to combine his identity as a knight with that of someone aspiring to holiness, a pilgrim.

As for other articulations of religious feeling in the narrative, Ethelstan finally utters a prayer which leads to a change in the country's situation:

"O Lord," quod he, "of moost magnyfycence,
Cast doun Thyn erysvn-to my prayeere!
Remembre nat vp-on my greet offence
But fro my synnes turne a-way Thy cheere,
Disespeired, stondying in doubyll were,
To lese my kyngdam, septre, and regalye,
But medyacioun of Thy Moder deere
Be gracious mede to saue my partye.

"My feith, myn hope, my trust, myn affyaunce All hoolly restith in Thy proteccyon;

My sheeld, my sheltroun, my suerd \& eek my launce

Be blont and feble, my power is bore doun;

But grace with mercy list be my champioun,

Thorgh Thy support my foon shal me encombre!"

["O Lord," said he, "of most magnificence,

Cast down Thy answer- to my prayer!

Remember not about my great offence

But from my sins turn away Thy face,

I was in despair, standing in double doubt,

To leave my kingdom, scepter, and regalia,

But for mediation of Thy dear mother

By gracious mercy to save my party.

"My faith, my hope, my trust, my confidence

All holy rests in Thy protection;

My shield, my army formation, my sword and likewise my lance

Are blunt and feeble, my power is down;

But I wish grace with mercy were my champion

Through Thy support few will trouble me!’]

(GW 209-222)

Again, emotions are discussed here at length, but they are analyzed in the religious context of supplications to God. Ethelstan talks about the "feith", "hope", "affyaunce" [confidence] that he puts in the Creator as the one who will help him to find a champion ready to confront Colebrand. As a result, he "lay in an agonye" [lay in agony] ( $G W$ 225), which again strengthens the emotional background of his prayer to our contemporary eyes. To quote Ailes, such pious passages increased the popularity of all versions of the Guy legend (Ailes 2007: 26). The combination of piety and elaborate discussions of emotions that this piety entailed is, however, more characteristic of the fifteenth-century poem than of the previous versions of the legend. 
The angel who is sent to Ethelstan by God adds a commentary to the discussion of the king's feelings since he alludes to his useless "despeir and dreede" [despair and dread] ( $G W$ 241). The two emotions should be abandoned by Ethelstan, since Jesus Christ to his "requeste hath cast doun His sight" [request has cast down His sight] ( $G W 245)$. The king will encounter a champion "clad as a pilgrim in a brood sclaveyn" [clad as a pilgrim in a broad pilgrim's cloak] ( $G W$ 251). Once Ethelstan realizes that God has granted him what he needs, he feels "humble affeccyoun" [humble affection] (GW 274) for the Creator. These are standard feelings that can be found in religious verse and prose, of course, but the wealth of changing emotions in Lydgate's Guy appears to demonstrate a new sensibility: secular narratives begin to be suffused with references to emotionality. The deeply religious sentiment may be found in a narrative primarily of secular nature since it simply narrated the adventures of a legendary knight turned hermit.

Importantly, emotions are not exclusively related to the religious context. In the poem, which ultimately ends with Guy's death as a hermit, there are numerous situations in which the characters weep. After all, medieval theology included the concept of the "gift of tears", which was related to divinity. In the religious context, weeping was proof of God's grace (Nagy 2017: 26). Moreover, as Bergqvist notes, the "shedding of tears was understood in different ways according to the situation at hand - it could be pleasurable, but it could also be an expression of devastation - which makes us aware of it being an ambiguous act, a gesture that was open to the interpretation of medieval agents and requires careful reading by medievalists today" (Bergqvist 2017: 77). It did not have to be a religious act; it could also be a political one. ${ }^{14}$ Furthermore, it could simply be a private manifestation of grief. In the poem, weeping is at first a sign of being emotionally devastated. Once Guy's son Raynbourne is away, his mother gives vent to her grief over his absence:

This seide Haralde being tho absent,

Out of this rewm to seke the sone of Guy,

Callid Raynbourne, in contrees adiacent,

And alle pe provyncis that stoodefaste by,

Wich in yong age was stole traytoruly,

By straunge merchauntis ongoodly lad away,

Felyce, his moder, wepyng tendrily,

For his absence compleynyng nyht and day.

[This said Harald, who was absent though

Out of his realm to seek the son of Guy,

Called Raynbourne, in adjacent countries,

14 Interestingly, the weeping of crusaders was both religious and political, as Jensen (2017: 98108) shows. 
And all the provinces that stood by,

Who in young age was stolen treacherously,

By foreign merchants taken away unlawfully,

Felice, his mother, wept tenderly,

Complaining day and night about his absence.]

(GW 169-176)

The wife of Guy, a crusader, bewails the loss of her son, who was stolen and sold somewhere by merchants trading in humans, which meant he was sold into slavery. In this respect, Felice and her husband seem to be well-matched, since once he becomes a miles Cristi, he is also presented as a sad person, if not a devastated one:

Guy, wonder sad of look and of vysage,

Feynt and wery, and dulled of travayll,

Made his excuse that he was ffale in age,

And out of ews more to be clad in mayll.

"My wil," quod he, "yif it myhte avayll,

The cruel ire of Danys to appeese,

For comoun profit, good wil shal nat ffayll,

My lyf iuparte to set thys lond in ese."

[Guy, exceedingly sad of look and on the face,

Weak and weary, and worn out by the journey

Made his excuse that he had fallen in years,

And was out of strength to be clad in a chain mail any more.

"My will', said he, "if it might hap,

Is to appease the cruel anger of the Danes,

For common profit, my good will shall not fail

I will jeopardise my life to set this land free.”]

(GW 353-360)

Guy's sadness results from the weakness and fatigue produced by his ascetic life as a pilgrim, but his approach to liberating the country from the Danes is more telling in terms of his emotional attitude. He is tired of the career of a knight and prefers to remain a hermit for the rest of his life. He is focused on religious contemplation. He no longer feels the need to confront more enemies on the battlefield, which used to happen before his spiritual transformation.

His final decision to fight against Colebrand is met with enthusiasm on the part of the king, which leads Ethelstan to overcome his difficult feelings:

The kyng, astoned, gan change cher and face,

And in maner gan wepyn for gladnesse,

And al attonys he gan hym to enbrace

In bothe his armes, of royall gentylnesse,

With offte kyssyng of ffeithfull kyndnesse,

With grete proffres on the tother syde

Of gold, of tresour, and of gret rychesse

With-inne his paleys yif he wolde abyde. 
[The king, astounded, began to change his facial expression, And in a manner began to weep out of gladness,

And all at once he began to embrace him

With both his arms, with royal gentleness,

With frequent kissing of faithful kindness,

With great gifts to the other side,

Gifts of gold, treasure, and great richness,

If he would stay in his palace.]

Here, the king's extensive weeping expresses joy at the prospect that the country may be saved by Guy. Cooper comments on weeping in Malory's Morte $D$ 'arthur that "weeping for joy is not unusual - a reaction that makes it oddly double-edged; and these responses are usually communal, almost choric as if to invite the readers to share the emotion" (Cooper 2015: 184). Weeping for joy establishes a sense of togetherness and the king's retinue are also probably expected to weep once the champion ultimately arrives, even though the narrative focuses only on the monarch's emotions. Again, as in the description of the Danes, who are both enraged and enraging, the audience are encouraged to get emotionally involved. The king, astonished that he sees Guy, at last, weeps out of gladness, and kisses him to show his affection for him. Here, weeping is not just a "bodily symptom", similar to blushing and thus difficult to control (Burrow 2004: 4), but a deliberate outpouring of emotions. Burrow writes that there existed, however, a theory about ladies as those who can weep for effect (Burrow 2004: 4). At this point of the narrative, we have to deal with yet another instance of weeping for effect: the king wishes to show Guy how important he is to the country and, therefore, he weeps for joy at the champion's arrival. Weeping out of joy is one of the medieval emotional regimes that Brandsma \& Larrington (2015) alluded to: it is expected of the king to react in this way. In turn, Guy is expected to reciprocate the emotional expression. $\mathrm{He}$ willingly does this, since:

At his departyng this avouh maad he,

With pitous wepyng, knelyng on his kne,

Vnto the kyng in fful humble entent:

"During me lyf, it may noon other bee,

Schall I neuer doon of this garnment."

[At his departure he made this vow,

With piteous weeping, kneeling on his knee,

Unto the king in full humble intention:

"During my life, it may not be otherwise,

I shall never take off this garment."] 
The characters have to control their feelings and express them in a sociallyacceptable manner, as William Reddy postulates in his Navigation of Feeling (2001) when he writes about the existence of "emotional regimes" over the centuries. This emotional community requires one to control one's feelings and their expression. The king and Guy become an "emotional community" such as Rosenwein discussed, understood as a group "in which people adhere to the same norms of emotional expression and value -or devalue - the same set of related emotions" (Rosenwein 2007: 2). Importantly, an emotional community may be a temporary entity, as happens in Guy. After all, the king will not be expected to weep for joy all the time, but now it is time for this, when the country is in danger of conquest by Danes and their atrocious giant.

Once Guy has met Colebrand in combat, he decides to abandon Felice for good and start an entirely holy life. Felice is a deeply devout person, who beseeches the poor folk she feeds "to praie for hir, and for his lordyslyf" [to pray for him, and for his lord's life] ( $G W$ 496); thus, she can understand Guy's decision. The two are still connected with mutual affection, despite going through yet another period of separation. A significant scene occurs when Guy sends Felice back his wedding ring:

\footnotetext{
Affter he sente in haste his weddying ryng

Vn-to his wyf, of trewe affeceyoun,

Praied hir to come to been at his deying.

[After he sent his wedding ring in haste,

To his wife, of true affection

Prayed to her to come and be at his death.]
}

$($ GW 518-520)

The true affection that once connected them is definitely spiritual rather than carnal now, if it ever was erotic in this poem. The fact that Guy sends back the ring once he has already spent two years in the hermitage shows that this is not the beginning of his celibacy, but rather a confirmation of what has already occurred. Yet, as he was dying and needed his one-time wife around him to do her duty, he sent for her, to which she responded with "hir besy care, / By a maner of wyfly dyllygence" [Her busy care, / In the manner of wifely diligence] ( $G W$ 521-522). She firstly ordered "his sepulture / With no gret cost, nor with no gret dyspense" [his sepulcher / With neither a great cost nor with a great expenditure] ( $G W$ 523-524), which was a tomb fully befitting a man who once lived in opulence, but voluntarily became poor.

There is no deathbed scene in the narrative as if to emphasize that Guy has renounced his earthly ties for good and there is no place for marital love between him and Felice any longer, yet the bond between the two spouses turns out to be as strong as in other versions of the legend, where there were obstacles to their 
marriage. In those other versions, the obstacles were overcome by their mutual attachment. In Lydgate's poem, Felice sees Guy only once he is dead, but her vehement emotional reaction testifies to the strength of the bond between them:

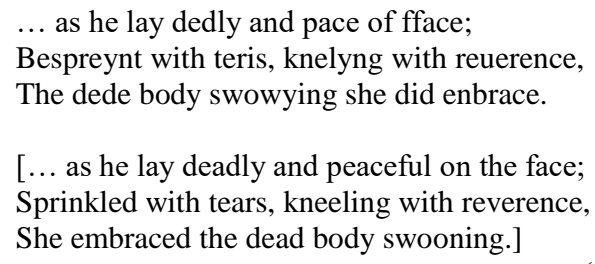

(GW 527-528)

Martha W. Driver writes about Lydgate's Guy that this is the version of the legend in which Felice is represented as a "pious mature widow" (Driver 2007: 136). The profuse weeping that she performs over the body of her husband is part of this characterization. Felice is pious, while her husband went even further in his religious devotion and became a holy man. Her tears are both personal and public, since she cries over Guy as a husband, but probably also as a holy man. After all, as Sahlin notes, "tears were a prominent part of the devotional lives and reputations of many lives of late-medieval women" (Sahlin 2017: 239). In the case of some of them, they were a sign of holiness, while in the case of others, the sobbing was thought to be "disorderly and demon-possessed" (Sahlin 2017: 239). In the case of Felice, the tears are the widow's natural reaction to the death of her husband, but they also strengthen her identification with religious observance. This passage illustrates the many possible aspects of weeping, since, to quote Sahlin, "the interpretations of tears are historically and culturally conditioned" (Sahlin 2017: 243). If Guy's identity was composed of both secular knighthood and the holiness of a hermit, Felice's reaction to his death is not easy to analyze, either. She embraces Guy both as his widow and as someone who understands the holiness of the life he chose before he died.

This is the one point at which Lydgate's poem is close to the Stanzaic Guy of Warwick, even though in the stanzaic version, Guy was still alive when Felice arrived and the emotions between them were quite different under the circumstances:

When that sche seighe hir lord Sir Gii

Sche wept and made doleful cri

With a ful reweful steven.

Sir Gii loked on hir thare,

His soule fram the bodi gan fare.

A thousand angels and seven

Underfenge the soule of Gii

And bar it with gret molodi

Into the blis of Heven. 


\author{
Than was that levedi ful of care \\ For hir lord was fram hir fare, \\ "Allas!" it was hir song. \\ Sche kist his mouthe, his chin also, \\ And wepe with hir eighen to \\ And hir hondes ssche wrong. \\ Gret honour dede our Lord for Gii: \\ A swete brathe com fram his bodi \\ That last that day so long \\ That in this world spices alle \\ No might cast a swetter smalle \\ As then was hem among. \\ [When she saw her lord Sir Guy \\ She wept and made a doleful cry \\ With a very rueful voice \\ Sir Guy looked on her there, \\ His soul from his body began to travel. \\ A thousand angels and seven \\ Seized the body of Guy \\ And bore it with great melody \\ Into the bliss of Heaven. \\ Then this lady was full of sorrow \\ For her lord went away from her, \\ "Alas!" it was her song. \\ She kissed his mouth, also his chin, \\ And wept with her eyes, too, \\ And she wrung her hands. \\ Our Lord did great honour for Guy: \\ A sweet breath came from his body \\ That lasted that day for so long \\ That all the spices of the world \\ Could not give out a sweeter smell \\ Than was among them.]
}

(Wiggins 2004: 3508-3528)

This passage shows how radically Lydgate reconfigures emotions in his poem. The emphasis on the religious aspects of the legend leads to a different treatment of emotions, and in Lydgate, Felice treats Guy's dead body with more awe, since she must have some intuition of Guy's holiness. The scene in question is crucial for the plot in that it not only completes Guy's transformation from a knight into a hermit, as he becomes a holy figure, but also in combining secular emotions with religious ones. The transformation of Guy was gradual, as Rouse maintains:

In the development of Guy's identity from secular knight to Christian pilgrim, we witness the characteristic model of identity (trans)formation found within this romance. Guy's identity is indeed altered, in that his motivation for chivalric deeds 
is located in his love for Christ, but his previous chivalric identity remains vital to his new identity as a martial-pilgrim: identity change in this romance is accretive in nature, rather than a matter of replacement-change.

(Rouse 2007: 104)

Love of adventure gradually becomes love for Christ, as Rouse writes, but the emotions in the narrative evolve as well. Felice first loves Guy as a husband; and then, she starts to understand his holiness when she bids farewell to him. Her gestures, which are full of reverence, make her even more of a pious woman. Her emotions are negotiated depending on the context she is in. She wavers between private feelings and religious devotion to adopt the identity of a consistently devout woman at what turns out to be also the end of her life.

Her reverence for Guy as a saint becomes so powerful that Felice wishes to be buried by his side. While he was still alive, he had given directions about his funeral: he asked Felice "in that place to burye hym anoon right, / Where as he lay afforn a small auhteer, / And that she sholde doon trewly hir deever" ( $G W$ 531-533). Felice cannot live any longer once her husband Guy is dead; fifteen days after his death, she dies and is buried by his side. She is presented here now as his alter ego, the female counterpart of his identity. This sheds a new light on the emotions she demonstrated while she was alive; importantly for us here, as one who charitably fed the poor, she embodied the ideal of what devout women should be like at the time (Driver 2007: 142).

The considerable scope is devoted to the community's reaction to his death here:

... old and yong of age,

Of dyuerse statys there cam gret multytude

With gret devocyoun to that hermytage;

And lyk a prynce with al the surplusage,

They took hym vp, and leyd hym to his grave,

Ordeyned of God afforn of hih corage

Ageyn the Danys thys regyoun to save.

[... old and young of age,

There came a great multitude of diverse spiritual conditions

With great devotion to that hermitage;

And like a prince with all that remained,

They took him up, and put him into his grave,

Previously foreordained by God, with high courage

To save the kingdom against the Danes]

$(G W 546-552)$

"Devocyoun" here also becomes related to a specific type of emotional attitude. The crowds wish to show their reverence towards Guy as a saint who has just passed away, even though at the same time he also has the status of a warrior hero. Grief is probably expected from them along with joy at the ultimate 
sanctification of a holy person, who was simultaneously a champion for his people. ${ }^{15}$ His status as miles Christi allows him to be revered as both the defender of the people and a holy person. Mourning becomes here both a communal and a religious act, but the two coexist without merging with each other. The grief needs to be transitory; rejoicing at the spiritual event of Guy becoming a saint in heaven happens instead. In this sense, Felice's reaction is more individualized; she treats Guy as a holy person but mourns over him as a husband. Thus, she does not share the communal reaction of triumph at Guy's achieving the highest degree of holiness, which comes after death. The end of the narrative demonstrates a fullyconscious performance of the feeling of grief on the part of the mourning community. Emotions are therefore a practice, not merely something that is given vent to. They are secular and religious feelings that are performed.

The way in which Lydgate developed the legend catered for "a desire for orthodoxy and for moral exempla as guidelines in a time of social change and growing spiritual anxiety", as Wilson (1975: 27) notes. At the same time, however, it must have satisfied the audience's need to express emotions in secular contexts instead of including them only in texts about religion. This need may have stemmed from the identity of at least some of the readers as middle-class people interested in literary texts. Emotions described in Lydgate's Guy do not exhaust the catalogue of feelings that can be found in fifteenth-century English literature. However, it is striking how many feelings, such as anger, devotion, and grief, are articulated in this text, which was preceded by many other versions of the Guy legend, in which stress was usually placed on other aspects. The fifteenth century was the period when emotions began to be expressed copiously in literature for lay audiences that also contained religious references, as Lydgate's poem does.

\section{REFERENCES}

\section{PRIMARY SOURCES}

Chance, Jane (ed.). 1999a. The Assembly of Gods. Medieval Institute Publications. (http://www.lib.rochester.edu/camelot/teams//asint.htm) (accessed 05/12/2018).

McCracken, Henry N. (ed.). 1997 [1911]. John Lydgate: The minor poems. Vol. II. Secular poems. Early English Text Society.

Price, Glanville (ed.). 1975. William, Count of Orange: Four Old French epics. J. M. Dent.

Wiggins, Alison (ed.). 2004. Stanzaic Guy of Warwick. Medieval Institute Publications. (https://d.lib.rochester.edu/teams/publication/wiggins-stanzaic-guy-of-warwick) (accessed 02/01/2019).

15 The social potential of grief in Middle English literature on the example of Chaucer's Knight's Tale has been explored by Edwards (2008: 361-384). 


\section{SECONDARY SOURCES}

Ailes, Marianne. 2007. Gui de Warewic in its manuscript context. In Alison Wiggins \& Rosalind Field (eds.), Guy of Warwick: Icon and ancestor, D. S. Brewer. 12-26.

Althoff, Gerd. 1998. Ira regis: Prolegomena to a history of royal anger. In Barbara H. Rosenwein (ed.), Anger's past: The social uses of an emotion in the Middle Ages, Cornell University Press. 59-74. DOI: 10.7591/9781501718694-007

Anderson, Benedict. 1991. Imagined communities: Reflections on the origins and spread of nationalism (2nd edn.). Verso.

Bergqvist, Kim. 2017. Tears of weakness, tears of love: Kings as fathers and sons in medieval Spanish prose. In Per Förnegård, Erika Kihlman, Mia Åkestam \& Gunnell Engwall (eds.), Tears, sighs and laughter: Expression of emotions in the Middle Ages, Kungl. Vitterhets Historie och Antikvitets Akademien. 77-97.

Bly-Calkin, Siobhan. 2005. Saracens and the making of English identity: The Auchinleck Manuscript. Routledge.

Boquet, Damien \& Piroska Nagy (eds.). 2010. Politiques des émotions au Moyen Âge. Firenze: SISMEl - Edizioni del Galuzzo.

Boquet, Damien \& Piroska Nagy. 2018. Medieval sensibilities: A history of emotions in the Middle Ages. Polity.

Brandsma, Frank \& Carolyne Larrington. 2015. Introduction. In Frank Brandsma, Carolyne Larrington \& Corinne Saunders (eds.), Emotions in medieval Arthurian literature: Body, mind, voice, D. S. Brewer. 1-10.

Brandsma, Frank, Carolyne Larrington \& Corinne Saunders (eds.). 2015. Emotions in medieval Arthurian literature: Body, mind, voice. D. S. Brewer.

Brewer, Derek (ed.). 1988. Studies in medieval English romances: Some new approaches. D. S. Brewer.

Burrow, John A. 2004. Gestures and looks in medieval narrative. Cambridge University Press. DOI: $10.1017 / \mathrm{CBO} 9780511483240$

Champion, Michael \& Andrew Lynch (eds.). 2015. Understanding emotions in early Europe. Brepols. DOI: 10.1484/M.EER-EB.5.108472

Chance, Jane. 1999b. The Assembly of Gods, introduction. In Jane Chance (ed.), John Lydgate. The Assembly of Gods, TEAMS. (https://d.lib.rochester.edu/teams/text/chance-theassembly-of-the-gods-introduction) (accessed 20/10/2020).

Connolly, Margaret. 1998. John Shirley: Book production in the noble household in fifteenthcentury England. Ashgate.

Cooper, Helen. 2015. Afterword: Malory's enigmatic kisses. In Frank Brandsma, Carolyne Larrington \& Corinne Saunders (eds.), Emotions in medieval Arthurian literature: Body, mind, voice, D. S. Brewer. 181-188.

Crane, Susan. 1986. Insular romance: Politics, faith, and culture in Anglo-Norman and Middle English literature. University of California Press. DOI: 10.7916/D8QZ2B94

Crofts, Thomas H. \& Robert Allen Rouse. 2009. Middle English popular romance and national identity. In Raluca Radulescu \& Cory Rushton (eds.), A companion to medieval popular romance, D. S. Brewer. 79-95.

Cullum, Patricia H. 2004. Introduction: Holiness and masculinity in medieval Europe. In Patricia H. Cullum \& Katherine J. Lewis (eds.), Holiness and masculinity in the Middle Ages, University of Wales Press. 1-7.

Cullum, Patricia H. \& Katherine J. Lewis (eds.). 2004. Holiness and masculinity in the Middle Ages. University of Wales Press.

Davies, Rees R. 2000. The first English empire: Power and identities in the British Isles 10931343. Oxford University Press.

DOI: https://doi.org/10.1093/acprof:oso/9780199257249.001.0001 
Driver, Martha W. 2007. 'In her owne persone semly and bewteus': Representing women in stories of Guy of Warwick. In Alison Wiggins \& Rosalind Field (eds.), Guy of Warwick: Icon and ancestor, D. S. Brewer. 133-153.

Edwards, Anthony S. G. 2007. The Speculum Guy of Warwick and Lydgate's Guy of Warwick: The non-romance Middle English tradition. In Alison Wiggins \& Rosalind Field (eds.), Guy of Warwick: Icon and ancestor, D. S. Brewer. 81-93.

Edwards, Elizabeth B. 2008. Chaucer's Knight's Tale and the work of mourning. Exemplaria 20(4). 361-384. DOI: 10.1179/175330708X371410

Field, Rosalind. 2009. The material and the problems. In Raluca Radulescu \& Cory Rushton (eds.), A companion to medieval popular romance, D. S. Brewer. 9-30.

Förnegård, Per, Erika Kihlman, Mia Åkestam \& Gunnell Engwall (eds.). 2017. Tears, sighs and laughter: Expression of emotions in the Middle Ages. Kungl. Vitterhets Historie och Antikvitets Akademien.

Frevert, Ute, Christian Bailey, Pascal Eitler, Benno Gammerl, Bettina Hitzer, Margrit Pernau, Monique Scheer, Anne Schmidt \& Nina Verheyen (eds.). 2014. Emotional lexicons: Continuity and change in the vocabulary of feeling 1700-2000. Oxford University Press. DOI: 10.1093/acprof:oso/9780199655731.001.0001

Garnett, Richard (ed.). 1903. English literature: An illustrated record. The Macmillan Company.

Gillingham, John. 2000. The English in the twelfth century: Imperialism, national identity and political values. The Boydell Press.

Hopkins, Andrea. 1990. The sinful knights: A study of Middle English penitential romance. Clarendon Press. DOI: 10.1093/acprof:oso/9780198117629.001.0001

Izdebska, Daria. 2015. The semantic field of ANGER in Old English. Unpublished PhD thesis: University of Glasgow.

Jensen, Kurt Villads. 2017. Crying crusaders. In Per Förnegård, Erika Kihlman, Mia Åkestam \& Gunnell Engwall (eds.), Tears, sighs and laughter: Expression of emotions in the Middle Ages, Kungl. Vitterhets Historie och Antikvitets Akademien. 98-108.

Jorgensen, Alice, Frances McCormack \& Jonathan Wilcox (eds.). 2015. Anglo-Saxon emotions: Reading the heart in Old English language, literature and culture. Ashgate.

Larrington, Carolyne. (forthc.). Embodiment and action. Unpublished MS.

Le Goff, Jacques. 1989. Rire au Moyen Âge. Cahiers du Centre du Recherche Historiques 3. DOI: 10.4000/ccrh.2918 (http://ccrh.revues.org/2918) (accessed 26/08/2018).

Lemmings, David \& Ann Brooks (eds.). 2014. Emotions and social change: Historical and sociological perspectives. Routledge.

Liliequist, Jonas (ed.). 2012. A history of emotions, 1200-1800. Routledge.

Maddern, Philippa, Joanne McEwan \& Anne M. Scott (eds.). 2018. Performing emotions in early Europe. Brepols. DOI: 10.1484/M.EER-EB.5.113963

Marculescu, Andreea \& Charles-Louis Morand Métivier. 2017a. Introduction. In Andreea Marculescu \& Charles-Louis Morand Métivier (eds.), Affective and emotional economies in medieval and early modern Europe, Palgrave Macmillan. 1-16.

Marculescu, Andreea \& Charles-Louis Morand Métivier (eds.). 2017b. Affective and emotional economies in medieval and early modern Europe. Palgrave Macmillan.

McNamer, Sarah. 2007. Feeling. In Paul Strohm (ed.), Middle English, Oxford University Press. 241-257. DOI: 10.1093/oxfordhb/9780199287666.013.0016

McNamer, Sarah. 2010. Affective meditation and the invention of medieval compassion. University of Pennsylvania Press.

Meale, Carol M. (ed.). 1994. Readings in medieval English romance. D. S. Brewer.

Mehl. Dieter. 1968. The Middle English romances of the thirteenth and fourteenth centuries. Routledge \& Kegan Paul.

Muir, Lynette. 1975. Introduction. In Glanville Price (ed.), William, Count of Orange: Four Old French epics, J.M. Dent. vii-xvi. 
Nagy, Piroska. 2017. The power of medieval emotions and change: From theory to some unexpected uses of spiritual texts. In Per Förnegård, Erika Kihlman, Mia Åkestam \& Gunnell Engwall (eds.), Tears, sighs and laughter: Expression of emotions in the Middle Ages, Kungl. Vitterhets Historie och Antikvitets Akademien. 13-39.

Newhauser, Richard. 2007. Sin: Essays on the moral tradition in the Western Middle Ages. Ashgate Variorum.

Nussbaum, Martha. 2003. Upheavals of thought: The intelligence of emotions. Cambridge University Press. DOI: 10.1017/CBO9780511840715

Pearsall, Derek. 1988. The development of Middle English romance. In Derek Brewer (ed.), Studies in medieval English romances: Some new approaches, D.S. Brewer. 11-35.

Radulescu, Raluca. 2009. Genre and classification. In Raluca Radulescu \& Cory Rushton (eds.), A companion to medieval popular romance, D. S. Brewer. 31-48.

Radulescu, Raluca \& Cory Rushton. 2009a. Introduction. In Raluca Radulescu \& Cory Rushton (eds.), A companion to medieval popular romance, D. S. Brewer. 1-8.

Radulescu, Raluca \& Cory Rushton (eds.). 2009b. A companion to medieval popular romance. D. S. Brewer.

Ramsey, Lee C. 1983. Chivalric romances: Popular literature in medieval England. Indiana University Press.

Reddy, William M. 2001. The navigation of feeling: A framework for the history of emotions. Duke University Press. DOI: 10.1017/CBO9780511512001

Richmond, Velma Bourgeois. 1996. The legend of Guy of Warwick. Garland Publishing.

Rikhardsdottir, Sif. 2017. Emotion in Old Norse literature: Translations, voices, contexts. D. S. Brewer.

Rosenwein, Barbara H. (ed.). 1998. Anger's past: The social uses of an emotion in the Middle Ages. Cornell University Press. DOI: 10.7591/9781501718694

Rosenwein, Barbara H. 2007. Emotional communities in the early Middle Ages. Cornell University Press.

Rosenwein, Barbara H. 2012. Theories of change in the history of emotions. In Jonas Liliequist (ed.), A history of emotions, 1200-1800. Routledge. 7-20.

Rouse, Robert Allen. 2007. An exemplary life: Guy of Warwick as medieval culture-hero. In Alison Wiggins \& Rosalind Field (eds.), Guy of Warwick: Icon and ancestor, D. S. Brewer. 94-109.

Sahlin, Clare L. 2017. Tears and weeping in the spirituality of St. Birgitta of Sweden. In Per Förnegård, Erika Kihlman, Mia Åkestam \& Gunnell Engwall (eds.), Tears, sighs and laughter: Expression of emotions in the Middle Ages, Kungl. Vitterhets Historie och Antikvitets Akademien. 239-254.

Schirmer, Walter F. 1961. John Lydgate: A study in the culture of the XVth century (trans. by Anne Keep). Methuen.

Stearns, Peter N. \& Carol Z. Stearns. 1985. Emotionology: Clarifying the history of emotions and emotional standards. The American Historical Review 90(4). 813-836. DOI: $10.2307 / 1858841$

Strohm, Paul (ed.). 2007. Middle English. Oxford University Press. DOI: 10.1093/oxfordhb/9780199287666.001.0001

Trigg, Stephanie. 2014. Introduction: Emotional histories - Beyond the personalization of the past and the abstraction of affect theory. Exemplaria 26(1). 3-15. DOI: 10.1179/1041257313Z.00000000043

Turville-Petre, Thorlac. 1994. Havelok and the history of the nation. In Carol M. Meale (ed.), Readings in medieval English romance, D .S. Brewer. 121-134.

White, Stephen D. 1998. The politics of anger. In Barbara H. Rosenwein (ed.), Anger's past: The social uses of an emotion, Cornell University Press. 127-152. DOI: $10.7591 / 9781501718694-010$ 
Wiggins, Alison. 2007. Synopsis of the Guy of Warwick narrative. In Alison Wiggins \& Rosalind Field (eds.), Guy of Warwick: Icon and ancestor, D. S. Brewer. 201-202.

Wiggins, Alison \& Rosalind Field (eds.). 2007. Guy of Warwick: Icon and ancestor. D. S. Brewer.

Wilson, Janet. 1975. Poet and patron in early fifteenth-century England: John Lydgate's Temple of glass. Parergon 11. 25-31.

Witalisz, Władysław. 2011. The Trojan mirror: Middle English narratives of Troy as books of princely advice. Peter Lang. 